\title{
O Papel do Tipo de Verbo na Concordância Verbal no Português Brasileiro
}

\author{
(The Role of Verb Type in Subject/Verb Agreement \\ in Brazilian Portuguese)
}

\author{
Maria Marta Pereira SCHERRE \\ (Universidade de Brasília/Universidade \\ Federal do Rio de Janeiro/CNPq) ${ }^{*}$ \\ Anthony Julius NARO \\ (Universidade Federal do Rio de Janeiro/CNPq) \\ Caroline Rodrigues CARDOSO \\ (Universidade de Brasília)
}

\begin{abstract}
In this article we discuss the effect of verb type on subject/verb agreement in Brazilian Portuguese and compare its effect with subject position and animacy. We analyze a sample of 4601 tokens (64 speakers) with verbs categorized along traditional lines (main, linking, and auxiliary) as well with verbs categorized along other traditional and generative lines (transitive, intransitive, linking, auxiliary/modal, and existential). None of the verb-type variables were selected as statistically significant. Subject position and animacy are the variables that reveal significant influence on subject/verb agreement; the only characteristic of the verb chosen is phonetic salience of the singular/plural opposition.
\end{abstract}

KEY-WORDS: subject/verb agreement; type of verb; subject position and animacy; phonetic salience.

REsumo: Discutimos neste texto o efeito do tipo de verbo na concordancia verbal no português brasileiro em confronto com o efeito da posição e da animacidade do sujeito. Analisamos 4601 dados (64 falantes) com os verbos categorizados numa perspectiva tradicional (nocional, de ligação e auxiliar) e também dados com os verbos categorizados

\footnotetext{
* Agradecemos ao Conselho Nacional de Desenvolvimento Científico e Tecnológico (CNPq) pelas bolsas de Produtividade em Pesquisa (PQ) e de Iniciação Científica (IC) que possibilitaram a realização deste trabalho.
}

D.E.L.T.A., 23:esp., 2007 (283-317) 
em outras perspectivas tradicionaias e gerativistas (transitivo, intransitivo, de ligação, auxiliar/modal, existencial). Em momento algum, o tipo de verbo revelou significância estatística. Posiçãa e animacidade são as variáveis que revelam efeitos. A única característica específica do verbo que influencia a concordância verbal é a saliência fônica da oposição singular/plural.

PALAVRAS-CHAVE: concordância verbal; tipo de verbo; posiz̧ão e animacidade do sujeito; saliência fônica.

\section{Introdução}

Nos últimos 30 anos, diversos estudos sobre o português brasileiro em uso têm evidenciado que a variação da concordância verbo/sujeito na terceira pessoa gramatical plural é controlada por diversas variáveis, entre as quais se destacam a saliência fônica da oposição singular/plural dos verbos; o traço semântico do sujeito; a posição do sujeito em relação ao verbo (cf., por exemplo, Naro \& Lemle (1976); Naro (1981); Guy (1981); Nicolau (1984); Bortoni-Ricardo (1985); Rodrigues (1987); Graciosa (1991); Scherre \& Naro (1997; 1998; 2006); Naro \& Scherre (1999a; 1999b); Anjos Almeida (1999); Monguilhott (2001); Vogt Barden (2004); Cardoso (2005); Scherre, Naro \& Cardoso (2005); Scherre, Cardoso \& Naro (2007)).

Em suas grandes oposições, o efeito dos fatores destas três variáveis é uniforme, no sentido de favorecer ou não a concordância plural, nos termos sintetizados e exemplificados em (1), (2) e (3):

(1) Verbo de oposição singular/plural mais saliente tende a favorecer concordância (exemplos em a); verbo de oposição menos saliente tende a desfavorecer concordância (exemplos em b):

a. Eles não FIZERAM as pazes agora (fez/fizeram - oposição mais saliente) $S \tilde{A} O$ todos dois casados (é/são - oposição mais saliente)

b. As criança também GOSTA... (gosta/gostam - oposição menos saliente) Se deixá, eles COME só feijão puro (come/comem - oposição menos saliente)

(2) Sujeito com traço semântico humano tende a favorecer concordância (exemplos em a); sujeito com traço semântico não-humano tende a desfavorecer concordância (exemplos em b): 
a. Meus pais também não QUERIAM que eu casasse com meu marido não Eles GOSTAM do assedio dos fãs. Eles VIVEM das pessoas, né?

b. Os verbos num CONCORDA os bonde DAVA a volta

(3) Sujeito à esquerda do verbo tende a favorecer concordância (exemplos em a); sujeito à direita do verbo tende a desfavorecer concordância (exemplos em b):

a. Eles VIERAM na primeira viagem de navio

Elas CHEGAM lá

Os cano já TÃO aparecendo

b. Aí, VEIO aqueles cara correno

E nisso me CHEGA três rapazes

TÁ doendo meus ouvido

Direta ou indiretamente, estudiosos de linha gerativa têm levantado a hipótese de que, subjacente ao efeito da posição e do traço semântico do sujeito está, de fato, o efeito do tipo de verbo, mais especificamente, a oposição entre verbos intransitivos inacusativos (chegar, aparecer, morrer, nascer), por um lado, e verbos intransitivos não-inacusativos (trabalhar, nadar, rir, dançar) e transitivos (fazer, falar, acreditar, dar), por outro (Mioto et al 2004: 119-169; Kato 2000). Tendo esta questão em mente, vamos discutir o comportamento do tipo de verbo em dados de uso do português brasileiro, comparando resultados de categorização dos verbos numa linha mais tradicional com categorização dos verbos numa linha mais gerativa. ${ }^{1}$

O fato fundamental de nossa reflexão é que, até o presente momento, SEJA QUAL FOR O CRITÉRIO USADO PARA A CATEGORIZAÇÃO DO VERBO, os resultados obtidos por análises variacionistas com apoio quantitativo (Weinreich, Labov \& Herzog 1968; Labov 1975; Sankoff 1988) evidenciam que o tipo de verbo ou não se mostra estatisticamente relevante para o entendimento da variação da concordância de número plural no português brasileiro (Cardoso 2005; Scherre, Naro \& Cardoso 2005; Scherre, Cardoso \& Naro 2007)

\footnotetext{
1 Segundo Mioto et al (2004: 148), o primeiro estudioso a propor a categorização dos verbos inacusativos foi Burzio (1986). A hipótese levantada, então, passou a ser conhecida como "Generalização de Burzio" ou hipótese inacusativa. Trata-se, na verdade, de uma análise, dentro do arcabouço teórico gerativo, das propriedades sintáticas destes verbos, antes tratadas de maneira dispersa e não como subcategoria coerente e estruturalmente significativa dos verbos intransitivos. Atualmente a categoria, bem como o próprio rótulo 'inacusativo', é utilizada também em outros tipos de análise.
} 
ou não apresenta resultados interpretáveis na linha da hipótese inacusativa (Monguilhott 2001; Monguilhott \& Coelho 2002), considerando ou não o conjunto mais amplo de dados na análise, a saber, orações com sujeitos expressos e não expressos.

Os dados que serviram de base para as análises aqui apresentadas foram produzidos por grupos de falantes do Rio de Janeiro e por uma só falante maranhense radicada em Brasília. Os dados do Rio de Janeiro foram coletados pelo Programa de Estudos sobre o uso da Língua (PEUL) um grupo de pesquisadores que se formou no início na década de 80 do século XX, com o objetivo de estudar a norma urbana não-culta do Rio de Janeiro, e são de duas naturezas. Um bloco de dados é proveniente do Corpus Censo: trata-se de 64 horas de fala de 64 falantes, estratificados em função do sexo, dos anos de estudos (de 1 a 11 anos) e da idade (de 7 a 71 anos), colhidas na década de 80 (Oliveira e Silva \& Scherre 1996: 53-81). O outro bloco de dados é proveniente de amostras de fala de 16 falantes do Corpus Censo, gravados novamente em 1999 e 2000, cerca de 18 anos depois (Paiva \& Duarte 2003: 13-29). Os dados da falante maranhense foram gravados por Caroline Rodrigues Cardoso entre 1999 e 2005, para efeito de sua dissertação de mestrado (Cardoso 2005).

\section{Análise dos dados da fala do Rio de Janeiro - Corpus do Programa de Estudos Sobre o Uso da Língua (PEUL)}

\subsection{Dados de 64 falantes da década de 80 do século XX: Corpus Censo}

A análise da concordância verbal nos dados do Corpus Censo do PEUL, iniciada em 1995, levou em conta o tipo de verbo, ao lado de outras restrições lingüísticas conhecidas como importantes para o entendimento da variação focalizada, a saber, saliência fônica da oposição singular/plural dos verbos; traço semântico do sujeito; tipo, posição e distância do sujeito em relação ao verbo; paralelismo discursivo ou marcas no discurso; paralelismo oracional ou marcas no sujeito (cf., por exemplo, Naro 1981; Scherre \& Naro 1991; 1993; 1997; 2006; Naro \& Scherre 1999a; 1999b; Nicolau 1984; Bortoni-Ricardo 1985; Rodrigues 1987; Graciosa 1991; Anjos Almeida 1999; Monguilhott 2001; Vogt Barden 2004; Cardoso 2005).

À época, munidos da tradicional classificação dos verbos em termos de nocionais, auxiliares e de ligação, que reflete um dos aspectos semânticos 
do verbo, codificamos cerca de 5000 dados produzidos pelos 64 falantes do Corpus Censo em função destas três categorias. A expectativa da análise era de que pudesse haver uma relação icônica entre a força semântica do verbo e a presença de concordância. Desta forma, tendo em vista que os verbos nocionais acumulam em si a informação semântica lexical e a informação semântica gramatical de número, a expectativa era a de que estes verbos favorecessem mais concordância verbal, na linha do princípio geral da saliência, que norteia a interpretação do efeito da saliência fônica, do traço semântico do SN sujeito, e da posição do SN sujeito em relação ao verbo, nos termos de Naro (1981) e de Naro \& Scherre (1999b). Em outro extremo, estariam os verbos de ligação que, nesta perspectiva, não constituem o núcleo do predicado, mas apenas elo sintático entre o sujeito e o predicativo, apontando para a expectativa de desfavorecimento da concordância verbal. Numa linha de efeito intermediário, estariam os verbos auxiliares, que não portam o significado lexical do evento verbal nem são apenas elos de ligação. Exemplos destes três tipos de verbo podem ser vistos a seguir:

(1) Verbos nocionais
a. Meus pais também não QUERIAM que eu casasse com meu marido não
b. As criança também GOSTA
c. ... se deixá, eles $C O M E$ só feijão puro
d. Aí, VEIO aqueles cara correno

(2) Verbos auxiliares em estruturas ativas e passivas
a. Os cano_já TÃO aparecendo
b. TÁ doendo meus ouvido
c. Eles $V \tilde{A} O$ devolver o que já foi pago?
d. A gente visita prefeitura, que os visitantes VAI visitar a prefeitura

(3) Verbos de ligação
a. os assunto $S \tilde{A} O$ muito ligados, né?
b. $S \tilde{A} O$ todos dois casados
c. Que hoje em dia as coisa $T A ́$ bem difícil mesmo
d. Eles FICARAM louco pelo Ceará

Submetidos os dados a tratamento quantitativo por meio de uma análise de regressão múltipla, os resultados expressos em termos de freqüências relativas corrigidas ou pesos relativos não revelaram, ao final da análise, relevância estatística no nível de significância normalmente arbitrado para 
as ciências sociais, de 0,05, o que equivale a estabelecer que os efeitos empiricamente verificados em nossos dados têm menos de $5 \%$ de chance de serem devidos ao acaso. Os parêntesis indicam que, no ponto especificado, o tipo de verbo não foi selecionado como estatisticamente significativo. Embora saibamos que o que importa para a seleção estatística é o fato de o nível de significância ser menor do que 0,05 , apresentamos o nível de significância de cada etapa, com o objetivo de explicitar que os efeitos simultâneos de outras variáveis retiram o efeito aparente do tipo de verbo da margem de relevância estatística e/ou modificam os pesos atribuídos aos seus fatores (Sankoff 1988; Guy 1998; Robinson; Lawrence \& Tagliamonte 2001; Scherre \& Naro 2003).

Para a obtenção dos pesos relativos, foi usado o pacote Varbrul, que projeta pesos para os fatores dos grupos de fatores ou variáveis independentes. Os pesos relativos - freqüências corrigidas - são calculados a partir das percentagens ou freqüências relativas observadas. O programa usado para o cálculo dos pesos relativos faz uma análise de regressão múltipla, projetando múltiplos pesos relativos para medir o efeito dos fatores dos grupos de fatores ou variáveis independentes, em diversas etapas de análises também denominadas de níveis de análise. No nível 0 (zero), o programa projeta o peso relativo global (denominado de input) e, a seguir, no nível 1, calcula os pesos relativos dos fatores de cada grupo de fatores isoladamente e seleciona o melhor, segundo rigorosos testes estatísticos (melhor aqui significa o grupo que mais dá conta da variação existente nos dados analisados). No nível 2, compara o grupo de fatores selecionado, par a par, com os demais grupos e seleciona o segundo grupo mais relevante do ponto de vista estatístico. Nos níveis seguintes, o programa procede da mesma forma (três a três; quatro a quatro e, assim, consecutivamente) até que o último grupo relevante tenha sido selecionado (Pintzuk 1988; Sankoff 1988; Robinson, Lawrence \& Tagliamonte 2001; Tagliamonte 2006; Guy \& Zilles 2007). Neste texto, utilizamos os pesos relativos dos diversos níveis de análise (no nosso caso, do nível 1 ao nível 12; ou do nível 1 ao nível 7) com o objetivo de evidenciar o comportamento da variável tipo de verbo nas diversas etapas de análise, isoladamente ou cruzada com os outros grupos de fatores.

Os resultados da TABELA 1a foram extraídos de uma análise contendo 12 grupos de fatores ou variáveis independentes. Além do tipo de verbo, a etapa de análise que produziu estes resultados leva em conta mais 11 
variáveis, todas estatisticamente significativas, selecionadas na seguinte ordem: (1) paralelismo discursivo; (2) tipo, posição e distância do sujeito em relação ao verbo; (3) saliência fônica; (4) paralelismo oracional; (5) anos de escolarização; (6) traço semântico do sujeito; (7) sexo; (8) contato com a mídia; (9) presença/ausência de que relativo; (10) faixa etária; (11) presença/ausência de pausa entre sujeito e verbo. No nível 1, estão os pesos relativos sem o cruzamento com as variáveis; no nível 2, adiciona-se a presença de (1) paralelismo discursivo (Par. disc.); no nível 3, tipo, posição e distância do sujeito em relação ao verbo (Pos.); no nível 4, a variável saliência fônica (Sali. fônica); e, no nível 12 - etapa em que o tipo de verbo teria a sua última chance de ser selecionado como estatisticamente significativo -, estão presentes as 11 variáveis selecionadas (Todas).

Tabela 1a: Efeito do tipo de verbo na concordância verbo/sujeito de terceira pessoa plural - dados de 64 falantes do

Rio de Janeiro da década de 80 do século XX

\begin{tabular}{|c|c|c|c|c|c|c|}
\hline \multirow[t]{2}{*}{$\begin{array}{l}\text { Tipo } \\
\text { de verbo }\end{array}$} & \multirow[t]{2}{*}{$\begin{array}{c}\text { Freqüência } \\
\text { de concordância }\end{array}$} & \multicolumn{5}{|c|}{ Peso relativo dos fatores por nível $(\mathrm{N})$ de análise } \\
\hline & & N1 & $\begin{array}{l}\text { N2 } \\
\text { Par. } \\
\text { disc. }\end{array}$ & $\begin{array}{l}\text { N3 } \\
\text { Pos. }\end{array}$ & $\begin{array}{l}\text { N4 } \\
\text { Sali. } \\
\text { fônica }\end{array}$ & $\begin{array}{l}\text { N12 } \\
\text { Todas }\end{array}$ \\
\hline Nocionais & $2017 / 2889=70 \%$ & 0,46 & 0,46 & 0,46 & $(\mathbf{0 , 5 1})$ & $(0,50)$ \\
\hline Auxiliares & $614 / 819=75 \%$ & 0,53 & 0,52 & 0,52 & $(0,48)$ & $(0,46)$ \\
\hline De ligação & $768 / 953=81 \%$ & 0,60 & 0,61 & 0,61 & $(0,49)$ & $(0,54)$ \\
\hline Total & $3399 / 4661=73 \%$ & & & & & \\
\hline Significância & & 0,000 & 0,000 & 0,000 & 0,512 & 0,103 \\
\hline
\end{tabular}

Os resultados da TABELA 1a revelam que as pequenas diferenças percentuais dos efeitos dos três fatores, contrários à nossa hipótese na relação diretamente inversa, permanecem, e com significância estatística, apenas até o nível 3 da análise de regressão múltipla (nocionais: 0,46; auxiliares: 0,53; de ligação: 0,61). No nível 4, os efeitos praticamente se nivelam 
(nocionais: 0,51; auxiliares: 0,48; de ligação: 0,49 ), com a entrada da variável saliência fônica, que retira dos verbos de ligação o seu efeito levemente favorecedor sobre a presença de concordância verbal. Em outras palavras, a entrada da saliência fônica corrige as freqüências relativas e, assim, se atribui o devido peso relativo a quem de direito. Isso ilustra a necessidade do cálculo dos pesos relativos, que tem como função refletir o efeito dos fatores subjacente às freqüências brutas observadas. $O$ leitor pode ver na TABELA $1 \mathrm{~b}$ o cruzamento do tipo de verbo e da saliência fônica e perceber um pouco de como os pesos relativos são projetados.

As pequenas diferenças percentuais atribuídas aos três tipos de verbos isoladamente - na margem direita da TABELA $1 \mathrm{~b}$ - diminuem ainda mais no cruzamento com a saliência. Os percentuais internos revelam pouca ou nenhuma diferença entre os três tipos de verbos, seja na oposição mais saliente $(85 \% ; 85 \%$; 85\%) seja na oposição menos saliente $(62 \% ; 61 \%$; $65 \%$ ). O efeito regular e evidente é entre os verbos de oposição mais saliente (tá/tão; fez/fizeram; é/são) e os verbos de oposição menos saliente (come/comem; gosta/gostam; diz/dizem), que revelam uma diferença mínima da ordem de 20 pontos percentuais e aos quais são atribuídos os pesos relativos de, respectivamente, 0,72 e 0,31 , retirados os efeitos das outras 10 variáveis estatisticamente significativas. Cumpre notar que a freqüência relativa bruta um pouco maior dos verbos de ligação (81\%) decorre da diferença de distribuição dos dados pelas categorias da saliência: $80 \%$ dos dados desta categoria são da oposição mais saliente (762/953).

Tabela 1b: Cruzamento do efeito do tipo de verbo e da saliência fônica na concordância verbo/sujeito de terceira pessoa plural - dados de

64 falantes do Rio de Janeiro da década de 80 do século XX

\begin{tabular}{l|c|l|l}
\hline \multirow{2}{*}{$\begin{array}{l}\text { Tipo de } \\
\text { Verbo }\end{array}$} & \multicolumn{2}{|c|}{ Saliência fônica } & Total \\
\hline Oposição mais saliente & Oposição menos saliente & \\
\hline Nocionais & $796 / 929=86 \%$ & $1221 / 1960=62 \%$ & $2017 / 2889=70 \%$ \\
Auxiliares & $402 / 473=85 \%$ & $212 / 346=61 \%$ & $\begin{array}{r}614 / 819=75 \% \\
\text { De ligação }\end{array}$ \\
& $644 / 762=85 \%$ & $124 / 191=65 \%$ & $768 / 953=81 \%$ \\
\hline Total & $1842 / 2164=85 \%$ & $1557 / 2497=62 \%$ & $4499 / 4661=73 \%$ \\
\hline
\end{tabular}




\subsection{Dados de 16 falantes do Corpus Censo Recontactados em 1999/2000}

Mesmo diante dos resultados apresentados na TABELA 1a (com pouca polarização, sem significância estatística e ainda contrários à hipótese formulada), a análise do tipo de verbo nunca saiu do foco da pesquisa de Naro \& Scherre, embora temporariamente deixada de lado nos dados do Corpus Censo da década de 80. Então, de posse dos dados dos 16 falantes do Corpus Censo recontactados no final da década de 90, o espírito investigativo provocou Naro \& Scherre a analisarem novamente o tipo de verbo nas cerca de 1200 construções relevantes para a concordância verbal dessa nova amostra.

Naro e seus auxiliares de iniciação científica fizeram uma categorização bastante detalhada desses novos dados. Além do aspecto semânticolexical do verbo, levaram em consideração a idéia de transitividade verbal como um fato dependente do contexto sintático, paralelamente à concepção de que os verbos apresentam uma transitividade preferencial (cf. Perini 1995: 161-173; 2006: 141-149, para discussão; Cunha \& Cintra 1985; Bechara 1999; Fernandes 1998). Com base nessa categorização, posteriormente ampliada e refinada por Scherre, foram estabelecidos 13 grandes blocos verbais, exaustivamente exemplificados a seguir.

(1) Verbos transitivos com sintagma nominal e/ou sintagma preposicional complemento superficialmente expresso
a. Tinha várias marcas de graxa assim na minha geladeira, que eles ABRIRAM minha geladeira
b. Eles não FIZERAM as pazes agora
c. Que eles MOSTRA a realidade. Eles num escondem não
d. Eles FAZEM filme assim, político, drama, romance
e. os cara FALAM inglês
f. que lá eles na igreja eles CANTAM parabéns
g. Eu andava na rua, eu olhava pras pessoas pra ver se [elas] TINHAM jóias minhas, assim, ali perto da onde eu morava
h. só valem as... as garota, os homens não VALEM nada aqui dentro?
i. prefiro um filme assim bíblico, desenhos, filmes que PASSAM pra gente um significado bom
j. $\quad \mathrm{Ai}$, mais tarde eles COMPRARAM um carrinho prá mim
k. eles num DERAM retorno nenbum de nada do que eu pedi
1. No quarto delas não MEXERAM em nada
$\mathrm{m}$. Eles GOSTAM do assedio dos fãs. Eles VIVEM das pessoas, né?
n. E eles $A C A B A R A M$ com o filme (...) porque eles BRINCA de fazer cinema
o. ... que eles $M A N D A M$ pra gente 
p. Será que todos os católicos $S A B E M$ disso?

q. Alguns colégio público CHEGA até o nível de um colégio particular

r. Várias coisas PASSAM pela cabeça, entendeu?

s. Agora o fato é que agora mesmo, no concurso do IME, dois alunos ENTRARAM com grau de recurso

t. Eu espero que eles MUDEM pra melhor ainda

(2) Verbos transitivos com oração desenvolvida

a. Não importa o que as outras pessoas PENSEM que eu seja ou deixe de ser

b. Eles SENTEM que vêm para uma terra diferente

c. Depois eles VIRAM que por ter passado por concurso público e militar eu podia realmente fazer isso

d. ...mas eles ACHAM que isso...

e. ...ontem era a pergunta se devia de trazê... as multinacionais deveriam trazê os seus empregados de fora. Então uns DISSERAM que não... e outros DISSERAM que sim

(3) Verbos transitivos com perífrase infinitiva

a. Foi que as famílias se matavam porque QUERIAM colocá a pessoa de seu clã como papa

b. Eles não $S A B I A M$ nem canta um samba, atrapalha a gente à beça

c. Eles não CONSEGUEM absorver um negócio desses

d. Tem pessoas que TENTA ficá ali

e. Eles $M A N D A M$ me chamá

f. Eles se gostaram ... Até que RESOLVERAM casar

g. agora que as filhas $P A R A R A M_{-}$de dá confiança para ele

h. Os investidores que investiram no filme dele COMEÇARAM a cobrar

(4) Verbos transitivos com complemento clítico

a. Não sei se as crianças me ACOMPANHARIAM, então teria que esperá o momento

b. inclusive tem umas família lá que me CONSIDERA como se eu fosse uma irmã delas

c. Foi que as famílias se MATAVAM porque queriam colocá a pessoa de seu clã como papa

d. E os dias se PERDEM na minha cabeça

e. Só que eles se CASARAM muito cedo, eles casaram com vinte e dois anos

f. Eu tô tomando café e os mico tão em cima da mesa. Mico selvagem, não é mico criado em casa não. Todo dia eu compro banana prá eles. Eu tô tomando café aqui, eles tão comendo aí na ponta da mesa comigo. Eles entram pela janela, tem um galho lá de árvore, aquilo lá encosta na janela (...) eles come lá. Eu sinto o maior prazer de ver os bichinho ali comendo. Cabô dali, eles vão embora. Não pego nenhum deles (...). Daí, cai lá dentro de casa, pula... Eles pula do galho, cai errado. Em vez de pará na janela, sai dentro de casa (...), se VIRA, a janela continua aberta, eles saem E minha vida é essa! 
(5) Verbos transitivos com complemento recuperado pela sintaxe ou pelo discurso
a. Tem professora aí novinha que os aluno nem RESPEITAM
b. ... é dez milhões que eles GASTAM
c. O tu ele USAM bastante
d. Que eles mostra a realidade. Eles num ESCONDEM não
e. Eu tô tomando café e os mico tão em cima da mesa. Mico selvagem, não é mico criado em casa não. Todo dia eu compro banana prá eles. Eu tô tomando café aqui, eles tão comendo aí na ponta da mesa comigo. Eles entram pela janela, tem um galho lá de árvore, aquilo lá encosta na janela (...) eles COME lá. Eu sinto o maior prazer de ver os bichinho ali comendo. Cabô dali, eles vão embora. Não pego nenhum deles (...). Daí, cai lá dentro de casa, pula... Eles pula do galho, cai errado. Em vez de pará na janela, sai dentro de casa (...), se vira, a janela continua aberta, eles saem E minha vida é essa!

(6) Verbos transitivos intransitivizados (sem recuperação explícita no contexto sintático e/ou discursivo)
a. E: Mas, eles conseguiam se comunicar direito ou tinham dificuldade? F:
Ah não, comunicava, comunicava direito, porque eu acho que eles já estavam há muitos ano aqui no Brasil. Eles FALAVAM você compreendia perfeitamente
b. Na hora não CANTAM, não evolui
c. Cê fala, cê cumprimenta, eles RESPONDEM
d. elas ESTUDARAM mais, entendeu?
e. Nossa, eles INTERROMPEM toda hora
f. mas sou obrigada a tá por dentro do assunto porque as crianças EXIGEM muito
g. os funcionários mais antigos GOSTAM
h. eu consegui também voltá meus olhos muito pro lado de como PENSAM os orientais na questão de religiosidade

\section{(7) Verbos intransitivos}
a. Hoje em dia, os pais TRABALHAM
b. eles BRIGAM quase todo dia
c. só VALEM as... as garota, os homens não valem nada aqui dentro?
d. elas LIGAM_cá prá casa da minha mãe
e. Porque a Mangueira a maioria são pessoas que $S A M B A$ no pé raiz
f. as crianças SOFREM... e que SOFREM, SOFREM
g. que eles VIAJAVAM muito, né?
h. VIERAM só os dois
i. Olha, até aqui CHEGARAM os duzentos pneus, se vai entrar ou não o problema é de vocês
j. E nisso me CHEGA três rapazes 
k. SÛ que eles se casaram muito cedo, eles CASARAM com vinte e dois anos

1. Eu tô tomando café e os mico T̃̃O em cima da mesa. Mico selvagem, não é mico criado em casa não. Todo dia eu compro banana prá eles. Eu tô tomando café aqui, eles tão comendo aí na ponta da mesa comigo. Eles ENTRAM pela janela, tem um galho lá de árvore, aquilo lá encosta na janela (...) eles come lá. Eu sinto o maior prazer de ver os bichinho ali comendo. Cabô dali, eles $V \tilde{A} O$ embora. Não pego nenhum deles (...). Daí, CAI lá dentro de casa, PULA... Eles PULA do galho, CAI errado. Em vez de pará na janela, $S A I$ dentro de casa (E. ri), se vira, a janela continua aberta, eles SAEM. E minha vida é essa!

\section{(8) Verbos auxiliares modais}

a. As multinacionais DEVERIAM trazer seus empregados de fora

b. As crianças não PODIAM ver

c. Todos os engenheiro TINHAM que sabê

(9) Verbo auxiliar ir mais infinitivo

a. Eles $V \tilde{A O}$ devolver o que já foi pago?

b. aí no final pensando que eles FOSSEM me ajudá, não me ajudaram

c. A gente visita prefeitura, que os visitantes VAI visitar a prefeitura

d. nossas bodas de prata VAI ser muito simples

e. dois eu senti que $I A$ acontecer

f. Olha, até aqui chegaram os duzentos pneus, se VAI entrar ou não o problema é de vocês

(10) Verbos auxiliares - estar, ficar, ir, ter, haver - mais gerúndio ou particípio

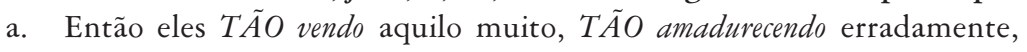
entendeu?

b. Agora, agora TĨO cortando tudo né, mas antes não, antes a coisa corria solta

c. Eu tô tomando café e os mico tão em cima da mesa. Mico selvagem, não é mico criado em casa não. Todo dia eu compro banana prá eles. Eu tô tomando café aqui, eles TÃO comendo aí na ponta da mesa comigo. Eles entram pela janela, tem um galho lá de árvore, aquilo lá encosta na janela (...) eles come lá. Eu sinto o maior prazer de ver os bichinho ali comendo. Cabô dali, eles vão embora. Não pego nenhum deles (...). Daí, cai lá dentro de casa, pula... Eles pula do galho, cai errado. Em vez de pará na janela, sai dentro de casa (...), se vira, a janela continua aberta, eles saem. E minha vida é essa!

d. porque as crianças aqui em casa FICAM a maior parte do tempo estudando

e. as terra só $V A I$ cedendo

f. É assim que as coisa $V \tilde{A O}$ aconteceno

g. Aí eu não sabia que eles TINHAM pulado o muro da minha casa

h. só existia a casa que era um bem comum que eles HAVIAM comprado 
(11) Verbo de ligação e auxiliar de passiva
a. Eles FICARAM louco pelo Ceará
b. Que hoje em dia as coisa $T A ́$ bem difícil mesmo
c. $S \tilde{A} O$ todos dois casados
d. os assunto $S \tilde{A} O$ muito ligados, né?
e. eles ERAM instruídos pra isso
f. mas todos eles $S \tilde{A} O$ aceitos no curso

(12) Verbo ser impessoal seguido de predicativo
a. ERAM mais homens
b. Porque ERA três irmãos
c. SÃO doze horas fora
d. ... é dez milhões que eles gastam
e. Num É cem quilos

(13) Verbos existenciais e impessoais
a. EXISTE pessoas que tem uma mentalidade doentia
b. EXISTIAM os aniversário de todo mundo
c. A fé Barrai fala (...) das grandes religiões que EXISTEM
c. TEVE outros dois lances que eu senti
d. TEVE engenheiros, médicos e.. arquitetos...
e. TINHA os carro dentro do hotel
f. TINHAM dois na mesma carteira
g. HAVIA muitos cinemas, não é?
h. Parece que $D A ́$ cinco horas
i. $D E U$ cinco horas
j. $\quad F A Z$ muitos anos que eu num vou pra lá

Com essa análise, a principal expectativa adicional era a de que pelo menos os verbos transitivos favorecessem mais concordância verbal, pelo fato de eles privilegiarem a ordem sujeito verbo (SV) no português brasileiro (Berlinck 1989: 102). O controle da presença ou ausência de complemento do verbo se faz necessário, a fim de buscar uma eventual semelhança de comportamento entre verbos transitivos sem complementos fisicamente expressos e verbos intransitivos, que se caracterizam exatamente por não terem complemento (ou argumento interno). Foram também consideradas as construções com verbos tradicionalmente classificados como impessoais e existenciais, tendo em vista a possibilidade de haver variação nesses casos, como se pode ver em exemplos das categorias 12 e 13, e o fato de este tipo de construção privilegiar a ordem verbo sujeito (VS). Em nossos dados, temos apenas um dado deste grupo na ordem SV (A fé Bahai 
fala (...) das grandes religiões que EXISTEM), em uma construção com que relativo, com concordância plural.

Na TABELA 2a, encontram-se os resultados para os treze grupos de verbos exemplificados acima, com pesos relativos de todos os níveis da análise de regressão múltipla. Observamos novamente que, ao lado das freqüências brutas de concordância, colocamos os pesos relativos do nível 1 de análise, sem correlação com outras variáveis, e os pesos relativos, em confronto com as variáveis selecionadas, de forma cumulativa, a saber: nível 2, com paralelismo discursivo (Par. disc.); nível 3, com paralelismo oracional (Par. orac.); nível 4, com traço semântico do sintagma candidato a controle da concordância (Traço sem.); nível 5, com saliência fônica da oposição verbal (Sali.fônica); nível 6, com falantes (Fal.); nível 7, com tipo, posição e distância do sujeito em relação ao verbo (Pos.).

Os níveis de significância da TABELA 2a revelam que, já a partir da entrada do paralelismo oracional, no nível 3, o tipo de verbo não seria selecionado como estatisticamente significativo, porque todos os valores estão acima de 0,05. Além do mais, há diversas interferências nos pesos relativos dos diversos fatores à medida que as variáveis estatisticamente significativas são adicionadas à análise de regressão múltipla.

Tendo em vista que o tipo de verbo assim analisado apresenta 13 categorias sem relevância estatística e que um dos objetivos finais da análise lingüística é a construção de um modelo o mais geral possível que dê conta dos fatos relevantes, efetuamos dois outros tipos de análises, passando a Navalha de Occam, nos termos sugeridos por Guy (1998: 39), para minimizar o número de fatores deste grupo e, então, "identificar as combinações de fatores que são LINGUISTICAMENTE mais gerais" ou "verificar quais são QUANTITATIVAMENTE similares, em termos de seus efeitos sobre a variação em estudo" [ênfases do autor]. Ressaltamos, adicionalmente, que a TABELA 2a contém diversos fatores com poucos dados, e que os fatores mais polarizados no nível 7 de análise $(0,70 ; 0,61 ; 0,61$; e $0,13)$ ocorrem todos com números menores de dados $(43 ; 25 ; 25$; e 20 ) (ver fatores 3, 4, 8 e 13). Isso sugere que os efeitos aparentes podem ser devidos a fatores aleatórios e é isso mesmo que a falta de significância está mostrando. 
Tabela 2a: Efeito do tipo de verbo na concordância verbo/sujeito de terceira pessoa plural - dados de 16 falantes do

Rio de Janeiro da década de 00 do século XXI

\begin{tabular}{|c|c|c|c|c|c|c|c|c|}
\hline \multirow[t]{2}{*}{$\begin{array}{l}\text { Tipo } \\
\text { de verbo }\end{array}$} & \multirow[t]{2}{*}{$\begin{array}{l}\text { Freqüência } \\
\text { de concordância }\end{array}$} & \multicolumn{7}{|c|}{ Peso relativo dos fatores por nível $(\mathrm{N})$ de análise } \\
\hline & & N1 & $\begin{array}{l}\text { N2 } \\
\text { Par. }\end{array}$ & $\begin{array}{l}\text { N3 } \\
\text { Par. } \\
\text { disc. }\end{array}$ & $\begin{array}{l}\text { N4 } \\
\text { Traço } \\
\text { orac. }\end{array}$ & $\begin{array}{l}\text { N5 } \\
\text { Sali. } \\
\text { sem. }\end{array}$ & $\begin{array}{l}\mathrm{N} 6 \\
\text { Fal. } \\
\text { fônica }\end{array}$ & $\begin{array}{l}\text { N7 } \\
\text { Pos. }\end{array}$ \\
\hline $\begin{array}{l}\text { 1) Transitivo } \\
\text { com SN e/ou } \\
\text { SPrep explicito }\end{array}$ & $234 / 282=83 \%$ & 0,52 & 0,52 & $(0,49)$ & $(0,45)$ & $(0,49)$ & $(0,51)$ & $(0,53)$ \\
\hline $\begin{array}{l}\text { 2) Transitivo } \\
\text { com oração } \\
\text { desenvolvida }\end{array}$ & $30 / 33=91 \%$ & 0,69 & 0,66 & $(0,58)$ & $(0,54)$ & $(0,61)$ & $(0,48)$ & $(0,49)$ \\
\hline $\begin{array}{l}\text { 3) Transitivo } \\
\text { em perífrase } \\
\text { infinitiva }\end{array}$ & $39 / 43=91 \%$ & 0,68 & 0,67 & $(0,62)$ & $(0,59)$ & $(0,66)$ & $(0,68)$ & $(0,70)$ \\
\hline $\begin{array}{l}\text { 4) Transitivo } \\
\text { com clítico }\end{array}$ & $21 / 25=84 \%$ & 0,54 & 0,52 & $(0,54)$ & $(0,55)$ & $(0,59)$ & $(0,61)$ & $(0,61)$ \\
\hline $\begin{array}{l}\text { 5) Transitivo } \\
\text { com complemento } \\
\text { recuperado pela } \\
\text { sintaxe } \\
\text { ou pelo discurso }\end{array}$ & $84 / 97=87 \%$ & 0,59 & 0,58 & $(0,54)$ & $(0,49)$ & $(0,55)$ & $(0,54)$ & $(0,52)$ \\
\hline $\begin{array}{l}\text { 6) Transitivo } \\
\text { Intransitivizado }\end{array}$ & $92 / 115=80 \%$ & 0,47 & 0,50 & $(0,48)$ & $(0,42)$ & $(0,49)$ & $(0,52)$ & $(0,49)$ \\
\hline 7) Intransitivo & $136 / 184=74 \%$ & 0,39 & 0,41 & $(0,41)$ & $(0,43)$ & $(0,44)$ & $(0,47)$ & $(0,50)$ \\
\hline $\begin{array}{l}\text { 8) Auxiliar } \\
\text { modal }\end{array}$ & $23 / 25=92 \%$ & 0,72 & 0,64 & $(0,63)$ & $(0,63)$ & $(0,71)$ & $(0,60)$ & $(0,61)$ \\
\hline $\begin{array}{l}\text { 9) Auxiliar } \\
+ \text { ndo/-do }\end{array}$ & $65 / 76=86 \%$ & 0,57 & 0,54 & $(0,55)$ & $(0,55)$ & $(0,49)$ & $(0,48)$ & $(0,49)$ \\
\hline $\begin{array}{l}\text { 10) Auxiliar } \\
\text { ir+infinitivo }\end{array}$ & $49 / 62=79 \%$ & 0,46 & 0,47 & $(0,45)$ & $(0,44)$ & $(0,32)$ & $(0,30)$ & $(0,30)$ \\
\hline $\begin{array}{l}\text { 11) Ligação } \\
\text { e auxiliar } \\
\text { de passiva }\end{array}$ & $200 / 235=85 \%$ & 0,56 & 0,56 & $(0,58)$ & $(0,62)$ & $(0,55)$ & $(0,54)$ & $(0,55)$ \\
\hline $\begin{array}{l}\text { 12) Impessoal } \\
\text { predicativo }\end{array}$ & $40 / 65=62 \%$ & 0,26 & 0,26 & $(0,40)$ & $(0,55)$ & $(0,46)$ & $(0,42)$ & $(0,32)$ \\
\hline $\begin{array}{l}\text { 13) Existencial } \\
\text { e impessoal } \\
\text { não-predictivo }\end{array}$ & $6 / 20=30 \%$ & 0,09 & 0,09 & $(0,16)$ & $(0,22)$ & $(0,26)$ & $(0,19)$ & $(0,13)$ \\
\hline $\begin{array}{l}\text { Total } \\
\text { Significância }\end{array}$ & $1019 / 1262=81 \%$ & 0,006 & 0,032 & 0,658 & 0,668 & 0,861 & 0,810 & 0,949 \\
\hline
\end{tabular}

Temos pelo menos duas formas de reduzir os 13 fatores da análise feita. Uma delas consiste em efetuar uma junção dos fatores à luz dos critérios até agora seguidos: o tipo semântico e a transitividade em função 
do contexto. Nessa linha, podemos fazer então as seguintes junções (ou amalgamações):

a. Verbos transitivos com complemento expresso após o verbo, no plano da sintaxe linear (categorias 1, 2 e 3);

b. Verbos transitivos sem complemento expresso após o verbo no plano da sintaxe linear, recuperado pela sintaxe (categoria 4) ou pelo discurso (categoria 5), verbo transitivo intransitivizado (categoria 6) e intransitivo (categoria 7);

c. Verbos auxiliares (categorias 8, 9 e 10);

d. Verbos de ligação e auxiliar de passiva (categoria 11);

e. Verbos impessoais e existenciais (categorias 12 e 13).

A outra forma consiste em efetuar uma junção à luz de uma sintaxe mais abstrata, que implicaria unir, de um lado, todos os verbos transitivos com os de uso preferencial transitivo (categorias de 1 a 6) versus os intransitivos (categoria 7), permanecendo inalteradas as junções das demais categorias, como explicitado acima em c, d; e.

Essas duas alternativas de análise são apresentadas na TABELA 2b/c: sombreados, temos os resultados estatísticos da alternativa b; não-sombreados, temos os resultados da alternativa c.

Independentemente do tipo de análise proposta nesta etapa, os resultados da TABELA 2b/c, a seguir, revelam mais uma vez a não relevância estatística da variável tipo de verbo, embora ainda permaneça, no último nível, mesmo sem seleção, o efeito desfavorecedor dos verbos existenciais e impessoais $(0,27)$. Embora estes verbos praticamente não tenham sintagma na posição de sujeito, à esquerda do verbo, o sintagma que se encontra à sua direita possibilita variação da marca de plural em verbos de diversas construções (ERAM mais homens/ERA três irmãos; $S \tilde{A O}$ doze horas/Num É cem quilos; EXISTIAM os aniversário/EXISTE pessoas; TINHAM dois/ TINHA os carro). Convém, todavia, salientar que, nessas duas análises, o tipo de verbo permanece com possibilidade de seleção até o nível 4, junto a paralelismo discursivo, paralelismo oracional e traço semântico do sintagma candidato a controle da concordância. É a entrada em cena da variável saliência fônica que, nas duas análises, retira o tipo de verbo da margem de significância estatística, porque essa variável reduz o efeito de 0,63/0,62 para $0,55 / 0,55$, atribuído aos verbos de ligação e auxiliar de passiva, um 
dos prováveis responsáveis pela suposta relevância estatística do tipo de verbo no nível 4 de análise (nível de significância 0,048/0,045), como também já tivemos oportunidade de argumentar com os resultados da TABELA 1a, para a amostra da década de 80 .

É também interessante registrar que paralelismo oracional, traço semântico e posição do sujeito interferem diretamente no efeito desfavorecedor da concordância atribuído aos verbos existenciais e impessoais: paralelismo oracional e traço semântico retiram-lhe efeito; posição lhe restitui. Vamos voltar a essa questão no final deste texto.

Tabela 2b/c: Efeito do tipo de verbo na concordância verbo/sujeito de terceira pessoa plural - dados de 16 falantes do Rio de Janeiro do fim da década de 90 do século XX

\begin{tabular}{|c|c|c|c|c|c|c|c|c|}
\hline \multirow[t]{2}{*}{$\begin{array}{l}\text { Tipo } \\
\text { de verbo }\end{array}$} & \multirow[t]{2}{*}{$\begin{array}{l}\text { Freqüência } \\
\text { de concordância. }\end{array}$} & \multicolumn{7}{|c|}{ Peso relativo dos fatores por nível $(\mathrm{N})$ de análise } \\
\hline & & N1 & $\begin{array}{l}\text { N2 } \\
\text { Par. } \\
\text { disc. }\end{array}$ & $\begin{array}{l}\text { N3 } \\
\text { Par. } \\
\text { orac. }\end{array}$ & $\begin{array}{l}\text { N4 } \\
\text { Traço } \\
\text { sem. }\end{array}$ & $\begin{array}{l}\text { N5 } \\
\text { Sali. } \\
\text { fônica }\end{array}$ & $\begin{array}{l}\text { N6 } \\
\text { Fal. }\end{array}$ & $\begin{array}{l}\text { N7 } \\
\text { Pos. }\end{array}$ \\
\hline $\begin{array}{l}\text { 1b) Transitivos } \\
\text { (cat. } 1 \text { a 3) }\end{array}$ & $302 / 357=85 \%$ & 0,56 & 0,55 & 0,51 & 0,48 & $(0,52)$ & $(0,53)$ & $(0,54)$ \\
\hline $\begin{array}{l}\text { 1c) Transitivos } \\
\text { (cat. } 1 \text { a } 6 \text { ) }\end{array}$ & $500 / 595=84 \%$ & 0,54 & 0,54 & 0,52 & 0,47 & $(0,52)$ & $(0,53)$ & $(0,53)$ \\
\hline $\begin{array}{l}\text { 2b) Intransitivos } \\
\text { transitivos sem } \\
\text { compl. explicito } \\
\text { e intransitivizados } \\
\text { (cat } 4,5,6 \text { e } 7 \text { ) }\end{array}$ & $334 / 422=79 \%$ & 0,46 & 0,48 & 0,47 & 0,45 & $(0,49)$ & $(0,50)$ & $(0,51)$ \\
\hline $\begin{array}{l}\text { 2c) Intransitivos } \\
\text { (cat. } 7 \text { ) }\end{array}$ & $136 / 184=74 \%$ & 0,39 & 0,41 & 0,42 & 0,43 & $(0,44)$ & $(0,47)$ & $(0,50)$ \\
\hline $\begin{array}{l}\text { 3b) Auxiliares } \\
\text { e modais }\end{array}$ & $137 / 163=84 \%$ & 0,55 & 0,53 & 0,52 & 0,52 & $(0,46)$ & $(0,43)$ & $(0,43)$ \\
\hline $\begin{array}{l}\text { 3c) Auxiliares } \\
\text { e modais }\end{array}$ & $137 / 163=84 \%$ & 0,54 & 0,52 & 0,51 & 0,52 & $(0,46)$ & $(0,43)$ & $(0,43)$ \\
\hline $\begin{array}{l}\text { 4b) Ligação } \\
\text { e aux. passiva }\end{array}$ & $200 / 235=85 \%$ & 0,57 & 0,57 & 0,58 & 0,63 & $(0,55)$ & $(0,55)$ & $(0,55)$ \\
\hline $\begin{array}{l}\text { 4c) Ligação } \\
\text { e aux. passiva }\end{array}$ & $200 / 235=85 \%$ & 0,56 & 0,56 & 0,58 & 0,62 & $(0,55)$ & $(0,54)$ & $(0,55)$ \\
\hline $\begin{array}{l}\text { 5b) Existenciais } \\
\text { e Impessoais }\end{array}$ & $46 / 85=54 \%$ & 0,21 & 0,21 & 0,34 & 0,47 & $(0,42)$ & $(0,37)$ & $(0,27)$ \\
\hline Total & $1019 / 1262=81 \%$ & & & & & & & \\
\hline Significância & & 0,000 & 0,000 & 0,038 & 0,048 & 0,523 & 0,295 & 0,785 \\
\hline Significância & & 0,000 & 0,000 & 0,016 & 0,045 & 0,326 & 0,213 & 0,805 \\
\hline
\end{tabular}


Tivemos sempre o cuidado de desconsiderar o fator posição à direita, da variável posição, para os casos de verbos existenciais e impessoais no sentido de não sobrepor categorização: praticamente todos esses casos só têm sintagma candidato a controle da concordância na posição à direita do verbo. Uma análise estatística mais adequada busca também minimizar a sobreposição de categorização pelos diversos grupos de fatores, ou seja, na medida do possível, busca grupos de fatores que evidenciem ortogonalidade - a livre co-ocorrência entre os fatores dos diversos grupos, nos termos Guy (1998: 29-34) e de Guy \& Zilles (2007: 52-57).

Passemos à análise desenvolvida por Cardoso (2005).

\section{Análise de dados de uma falante maranhense residente em Brasília}

Com dados gravados em 19992004 e 2005, de uma falante maranhense radicada em Brasília, Cardoso (2005) assume reflexões da gramática gerativa a respeito da não homogeneidade dos verbos tradicionalmente classificados como intransitivos, baseada na generalização expressa em Mioto et al. (2004: 119-169) sobre os verbos denominados inacusativos, que constitui uma ampliação da denominada generalização de Burzio ou hipótese inacusativa, para estabelecer uma relação entre o traço semântico do $\mathrm{SN}$, a ordem do SN em relação ao verbo e eventual ausência de concordância verbal.

Seguindo o raciocínio de estudiosos de linha gerativa, podemos, inicialmente, falar em dois grandes blocos de verbos de acordo com o argumento que selecionam. O primeiro bloco é o constituído pelos verbos que selecionam dois argumentos, um externo (que nasce à esquerda do verbo e dele recebe caso nominativo) e um interno (que nasce à direita do verbo e dele recebe caso acusativo, quando o argumento em jogo não é regido por preposição). São os tradicionais transitivos. O segundo bloco é o dos que selecionam um único argumento (monoargumentais), os tradicionais intransitivos, que, pela visão gerativista, se subdividem em dois grupos, porque não constituem uma classe homogênea (cf. detalhes da argumentação em Coelho 2000b: 84-91 e Mioto et al. 2004: 146-169; cf. também Brito \& Duarte 2003; Duarte 2003; Eliseu 1984). Um grupo contém verbos que só selecionam argumento interno, que nasce à direita, mas deles 
não recebe caso acusativo, fato que motiva a denominação de verbos inacusativos (chegar, aparecer, morrer, nascer etc.). ${ }^{2} \mathrm{O}$ outro grupo é constituído por verbos que selecionam só argumento externo, que nasce à sua esquerda, e deles recebe caso nominativo (trabalhar, nadar, rir, dançar etc.), os verdadeiros intransitivos aos quais denominaremos intransitivos nãoinacusativos ou de, apenas, intransitivos. ${ }^{3}$ Os exemplos em (14), (15) e (16) ilustram a classificação:

(14) Transitivos

a. Eles num CONHECE ninguém lá

b. (Os mala) OLHARAM a minha bolsa, né?

c. Muitos $F E Z$ (inscrição para ganhar lote)

d. (Muitos) RECEBERAM (lote) de novo

(15) Intransitivos não-inacusativos

a. Meus menino JANTARAM

b. Eles $R I$ demais

c. Lá onde eles MORA (...)

(16) Intransitivos inacusativos

a. As menina CHEGARAM

b. MORREU dois

c. Eles NASCERAM na casa da minha mãe

2 Em verdade, os próprios verbos inacusativos, pelo menos com relação à ordem, não constituem uma classe homogênea (cf. Coelho 2000a: 120; 142; Coelho 2000b; Duarte \& Silva 2005; Ciríaco \& Cançado 2004: 218-223). Além do mais, Votre \& Naro (1989) e Pilati (2006) observam que a ordem VS também pode se dar com verbos transitivos, por razões de ordem funcional e/ou sintática, especialmente, ponderamos nós, quando entram em jogo estruturas não-plurais como "cem mil cruzeiros faturou a nossa barraca" ou "Ergue o braço o juiz". A discussão sobre as motivações da ordem SV/VS rendeu um bom debate na lingüística brasileira, publicado pela revista DELTA (cf. Votre \&Naro 1989; Nascimento 1990; Dillinger 1991; Naro \& Votre 1992). Este debate é agora retomado pela tese de doutorado de Pilati (2006), com abordagem gerativista, que estabelece laços, embora tênues, com uma abordagem funcionalista. Para mais detalhes sobre a análise funcionalista, ver Naro \& Votre (1999).

3 Encontra-se na literatura pertinente a terminologia ergativo para inacusativo e, conseqüentemente, inergativo para intransitivo (cf. Eliseu 1984). Não a adotamos neste trabalho por considerá-la inadequada. Ver a base de nossa discordância em, por exemplo, Lyons (1979: 371-372) e Du Bois (1987: 808). 
Uma das evidências do caráter interno dos argumentos selecionados pelos verbos inacusativos se dá, segundo Mioto et al. (2004: 162), pela ausência quase categórica de concordância em estruturas do tipo "chegou as cartas" (cf. ex. 14B - "morreu dois"), quando o argumento não é alçado para a posição pré-verbal. Nas palavras de Mioto et al. (2004: 162), "isso dá conta da perda de concordância na língua em tais sentenças, pois mostra que o falante trata (...) as cartas como argumento interno, COM O QUAL O VERBO JAMAIS CONCORDARÁ" [ênfases nossas].

Ainda, segundo Mioto et al (2004: 148), "para demonstrar que existe a classe de verbos inacusativos dois passos são necessários: o primeiro é mostrar que existem verbos que têm argumento interno, mas não têm argumento externo. O segundo passo exige que mostremos que, se um DP [análogo ao antigo sintagma nominal (SN)] aparece na posição de sujeito de um verbo dessa classe, este DP não é argumento externo deste verbo. Vemos aqui a necessidade de reforçar a diferença entre ser sujeito da sentença e ser argumento externo do verbo".

Assim, para os referidos autores, o fato de ser possível demonstrar que o verbo inacusativo não seleciona argumento externo (porque qualquer tipo de DP pode ocorrer na posição pré-verbal de um verbo inacusativo) permite que esta classe seja ampliada, no português brasileiro, para abarcar os verbos tradicionalmente classificados como de ligação, modais, existenciais, impessoais e auxiliares de estruturas ativas e passivas, incluindo o verbo ir significando futuro. Trabalhamos com a generalização apresentada por Mioto et al (2004), tendo em vista que nosso objetivo central é verificar se o tipo de verbo tem realmente algum efeito na variação da concordância verbal, embora muitas questões polêmicas envolvam a configuração dos verbos inacusativos, especialmente com a análise de dados produzidos em circunstâncias reais.

Além das idéias expressas em Mioto et al. (2004), seguimos a linha de pensamento de Duarte (2003: 539-542) a respeito das classes de verbos, e estabelecemos uma classificação detalhada que leva em conta, além dos já demonstrados transitivos, intransitivos e inacusativos, mais quatro grupos de inacusativos generalizados, conforme exemplificamos em (17), (18), (19) e (20): 
(17) Verbos auxiliares/inacusativos: verbos auxiliares em estruturas ativas e passivas, que também não entram em jogo na seleção do argumento externo ${ }^{4}$
a. Os menino $V \tilde{A} O$ dormir sem jantar?
b. Eles TINHAM colocado luz (...)
c. FOI tirado suas trompas (...)

(18) Verbos de ligação/inacusativos: selecionam uma SC - small clause -, com posição de sujeito lexicalmente preenchida ou recuperada pelo discurso
a. Muitos anos de vida $S \tilde{A} O$ meus voto de felicidade
b. Tem muitas coisas assim que $S \tilde{A} O$ meio desagradável
c. É muito cara as passage

(19) Verbos existenciais/inacusativos: verbos tradicionalmente classificados como tendo um argumento externo, pelo fato de não se ter em mente a tipologia inacusativa e que, segundo Mioto et al (2004), obscurece o fato de que este argumento dificilmente ocupa a posição de sujeito, à esquerda do verbo ${ }^{5}$

a. TINHAM lá uns pessoal, né?

b. TINHA os professores

(20) Verbos impessoais/inacusativos: verbos tradicionalmente classificados como impessoais - considera-se que não selecionam argumento algum, mas apresentam a posição de argumento interno superficialmente preenchida
a. É jornais e mais jornais
b. $S \tilde{A} O$ três passage
c. FEZ três anos que eu moro lá

Os resultados desta análise, com todos os níveis da análise de regressão para o tipo de verbo, podem ser vistos na TABELA 3. O nível 1 apresenta a variável em análise isoladamente. No nível 2, entra no cruzamento a saliência fônica (Sali. fônica). No nível 3, o tipo de verbo está cruzado com o traço semântico do sujeito (Traço sem.). Nos níveis 4 e 5, entram paralelismo oracional (Par. orac.) e paralelismo discursivo (Par. disc.), respectivamente. Por fim, adiciona-se a posição do sujeito (Pos.). No nível 6, o tipo de verbo cruza-se com todas as variáveis selecionadas. Nesta rodada,

\footnotetext{
4 Tivemos o cuidado de separar estes verbos tendo em vista que eles, embora não selecionem argumento interno, podem ocorrer em uma estrutura transitiva, com sujeito AGENTE. Além disso, fizemos uma etapa de análise sem os sujeitos ocultos (ou nulos) para melhor comparar com os resultados de Monguilhott (2001), mas, mesmo assim, a variável tipo de verbos continuou sem significância estatística.

5 A análise dos verbos existenciais e dos impessoais na classe dos inacusativos também está sujeita a controvérsia. Para a discussão, ver Franchi, Negrão \& Viotti (1998).
} 
agrupamos os existenciais com os impessoais por causa da escassez de dados. Relembramos que os pesos relativos sem parêntesis indicam que haveria possibilidade de seleção da variável ao nível de significância de 0,05 ; os pesos dentro dos parêntesis indicam impossibilidade de seleção da variável com o mesmo nível de significância.

Os resultados da TABELA 3 evidenciam mais uma vez que o tipo de verbo não revela relevância estatística para o entendimento da variação da concordância verbo/sujeito no português brasileiro, mesmo numa análise que usa a categorização inacusativa sugerida por Burzio. $\mathrm{O}$ tipo de verbo apresenta possibilidade de seleção apenas no nível 2, e apenas os verbos impessoais e existenciais/inacusativos evidenciam tendência de efeito desfavorecedor neste nível $(0,24)$. Os demais verbos inacusativos, neste nível, revelam efeito intermediário $(0,45 ; 0,46$ e 0,41$)$. Ainda no nível 2, os verbos transitivos e intransitivos não-inacusativos, na forma esperada, revelam efeito favorecedor da concordância $(0,60 ; 0,69)$, efeito este que diminui para os verbos transitivos com a mensuração do traço semântico do sujeito (de 0,60 diminui para 0,54) e das demais variáveis (de 0,54 para $0,48)$. O efeito dos verbos transitivos, ao final da análise, se nivela aos dos inacusativos $(0,48)$. Além disso, a entrada da variável traço semântico, no nível 3, retira da cena estatística a variável tipo de verbo (significância $0,358)$ e o efeito final dos verbos impessoais e existenciais/inacusativos $(0,48)$ é semelhante aos pesos relativos dos demais verbos inacusativos: todos em torno de 0,50 . Ao final da análise, os intransitivos exibem 0,66 de peso relativo, efeito favorecedor da concordância, como seria esperado, mas sem significância estatística do grupo. Além disso, esse é o fator que tem o menor número de dados (30 dados), fato que poderia ter contribuído para a não seleção do tipo de verbo.

Em síntese, o tipo de verbo, com relação à concordância, levando em consideração todo o conjunto de dados relevantes, além de não apresentar significância estatística, não revela indícios de direção coerente. 
Tabela 3: Efeito do tipo de verbo na concordância verbo/sujeito de terceira pessoa plural - dados de uma falante do Maranhão residente na periferia de Brasília - gravações de 19992004 e 2005

\begin{tabular}{|c|c|c|c|c|c|c|c|}
\hline \multirow[t]{2}{*}{$\begin{array}{l}\text { Tipo } \\
\text { de verbo }\end{array}$} & \multirow[t]{2}{*}{$\begin{array}{l}\text { Freqüência } \\
\text { de concordância }\end{array}$} & \multicolumn{6}{|c|}{ Peso relativo dos fatores por nível $(\mathbf{N})$ de análise } \\
\hline & & N1 & $\begin{array}{l}\mathbf{N 2} \\
\text { Sali. } \\
\text { fônica }\end{array}$ & $\begin{array}{l}\text { N3 } \\
\text { Traço } \\
\text { sem. }\end{array}$ & $\begin{array}{l}\text { N4 } \\
\text { Par. } \\
\text { disc. }\end{array}$ & $\begin{array}{l}\text { N5 } \\
\text { Par. } \\
\text { orac. }\end{array}$ & $\begin{array}{l}\text { N6 } \\
\text { Pos. }\end{array}$ \\
\hline 1) Transitivos & $105 / 197=53 \%$ & $(0,51)$ & 0,60 & $(0,54)$ & $(0,51)$ & $(0,49)$ & $(0,48)$ \\
\hline 2) Intransitivos & $18 / 30=60 \%$ & $(0,58)$ & 0,69 & $(0,64)$ & $(0,63)$ & $(0,66)$ & $(0,66)$ \\
\hline 3) Inacusativos & $31 / 62=50 \%$ & $(0,48)$ & 0,45 & $(0,40)$ & $(0,42)$ & $(0,43)$ & $(0,47)$ \\
\hline $\begin{array}{l}\text { 4) Auxiliares e modais/ } \\
\text { inacusativos }\end{array}$ & $25 / 47=53 \%$ & $(0,51)$ & 0,46 & $(0,43)$ & $(0,40)$ & $(0,40)$ & $(0,42)$ \\
\hline $\begin{array}{l}\text { 5) Ligação/ } \\
\text { inacusativos }\end{array}$ & $45 / 75=60 \%$ & $(0,58)$ & 0,41 & $(0,50)$ & $(0,57)$ & $(0,55)$ & $(0,53)$ \\
\hline $\begin{array}{l}\text { 6) Impessoais } \\
\text { e existenciais/ } \\
\text { inacusativos }\end{array}$ & $18 / 52=35 \%$ & $(\mathbf{0 , 3 3 )}$ & 0,24 & $(\mathbf{0 , 4 3 )}$ & $(\mathbf{0 , 4 2 )}$ & $(\mathbf{0 , 5 0 )}$ & $(\mathbf{0 , 4 8 )}$ \\
\hline Significância & & 0,097 & $\mathbf{0 , 0 0 0}$ & 0,358 & 0,348 & 0,454 & 0,684 \\
\hline Total & $242 / 464=52 \%$ & & & & & & \\
\hline
\end{tabular}

\section{Nova análise dos dados dos 16 falantes do Corpus Censo recontactados em 1999/2000}

Assumimos a análise de Cardoso (2005) e reanalisamos os dados dos 16 falantes recontactados pelo PEUL. A seguir, no item 5, efetuamos uma análise sintética para as duas amostras e comparamos as duas análises, no que diz respeito à variável tipo de verbo, sempre sem relevância estatística, e as demais variáveis lingüísticas, com relevância estatística nas duas amostras. Buscamos, ao final, fazer algumas reflexões que podem nortear a continuidade da análise nestes e em novos estudos.

Os resultados com seis grupos de verbos, à semelhança da análise apresentada na TABELA 3, podem ser vistos na TABELA 4. 
Tabela 4: Efeito do tipo de verbo na concordância verbo/sujeito de terceira pessoa plural - dados de 16 falantes do Rio de Janeiro do final da década de 90 do século XX

\begin{tabular}{|c|c|c|c|c|c|c|c|c|}
\hline \multirow[t]{2}{*}{$\begin{array}{l}\text { Tipo } \\
\text { de verbo }\end{array}$} & \multirow[t]{2}{*}{$\begin{array}{l}\text { Freqüência } \\
\text { de concordância }\end{array}$} & \multicolumn{7}{|c|}{ Peso relativo dos fatores por nível $(\mathrm{N})$ de análise } \\
\hline & & N1 & $\begin{array}{l}\text { N2 } \\
\text { Par. } \\
\text { disc. }\end{array}$ & $\begin{array}{l}\mathrm{N} 3 \\
\text { Par. } \\
\text { orac. }\end{array}$ & $\begin{array}{l}\mathrm{N} 4 \\
\text { Traço } \\
\text { sem. }\end{array}$ & $\begin{array}{l}\text { N5 } \\
\text { Sali. } \\
\text { fônica }\end{array}$ & \begin{tabular}{l|} 
N6 \\
Falantes
\end{tabular} & $\begin{array}{l}\text { N7 } \\
\text { Pos. }\end{array}$ \\
\hline 1) Transitivos & $496 / 588=84 \%$ & 0,55 & 0,55 & 0,52 & $\mathbf{0 , 4 7}$ & $(0,53)$ & $(0,53)$ & $(0,54)$ \\
\hline 2) Intransitivos & $56 / 74=76 \%$ & 0,41 & 0,41 & 0,38 & 0,35 & $(0,41)$ & $(0,45)$ & $(0,48)$ \\
\hline 3) Inacusativos & $86 / 117=72 \%$ & 0,37 & 0,39 & 0,42 & 0,46 & $(0,45)$ & $(0,47)$ & $(0,50)$ \\
\hline $\begin{array}{l}\text { 4) Auxiliares/modais: } \\
\text { inacusativos }\end{array}$ & $137 / 163=84 \%$ & 0,54 & 0,52 & 0,52 & 0,52 & $(0,46)$ & $(0,43)$ & $(0,43)$ \\
\hline $\begin{array}{l}\text { 5) Ligação: } \\
\text { inacusativos }\end{array}$ & $200 / 235=85 \%$ & 0,56 & 0,56 & 0,58 & 0,63 & $(\mathbf{0 , 5 5})$ & $(0,55)$ & $(0,55)$ \\
\hline $\begin{array}{l}\text { 6) Existenciais } \\
\text { e impessoais: } \\
\text { inacusativos }\end{array}$ & $46 / 85=54 \%$ & 0,21 & 0,21 & 0,34 & 0,47 & $(0,41)$ & $(0,36)$ & $(0,27)$ \\
\hline Total & $1019 / 1262=81 \%$ & & & & & & & \\
\hline Significância & & 0,000 & 0,000 & 0,018 & 0,039 & $\begin{array}{l}\mathbf{0 , 3 5 8} \\
\end{array}$ & 0,277 & 0,849 \\
\hline
\end{tabular}

Nesta etapa de análise, observamos que a variável tipo de verbo apresenta desempenho estatisticamente significativo até o nível 4 (significâncias $0,000 / 0,000 / 0,018 / 0,039)$, quando se conjuga com paralelismo discursivo, paralelismo oracional e traço semântico do sujeito. Poderia ser selecionada, mas, ainda assim, com pesos relativos fora do esperado, porque o efeito dos transitivos $(0,47)$ se iguala ao dos intransitivos/inacusativos $(0,46)$ e o efeito dos intransitivos não-inacusativos fica relativamente baixo $(0,35)$. O fator que mais favoreceria a concordância é o dos verbos de ligação $(0,63)$, também inacusativos, cujo efeito é novamente diminuído (de 0,63 para 0,55) com a entrada da saliência fônica (no nível 5), que, por sua vez, retira o tipo de verbo da faixa de significância estatística (significância 0,358 ), à semelhança do que ocorreu nos resultados das TABELAS 1a; $2 \mathrm{a} ; 2 \mathrm{~b} / \mathrm{c}$; e 3 . Ao final da análise de regressão, no nível 7, apenas os verbos existenciais e impessoais revelam efeito desfavorecedor da concordância $(0,27)$, mas ainda sem significância estatística, com um nível de significância exacerbado $(0,849)$ com a entrada da variável posição.

Ainda não completamente convencidos da inoperância da variável tipo de verbo, recorremos novamente à metáfora da Navalha de Occam e decidimos analisar os dois últimos conjuntos de dados em termos de uma oposi- 
ção binária: INACUSATIVOS AMPLIADOS (englobando inacusativos, existenciais/inacusativos e impessoais/inacusativos) versus DEMAIS verBos.

\section{Síntese da análise dos dados da falante maranhense e dos 16 falantes do Rio de Janeiro}

Para esta etapa de análise binária, levamos em consideração a argumentação de base gerativa nos seguintes termos:

1) $\mathrm{O}$ argumento dos verbos inacusativos nasce na posição de argumento interno, ou seja, à direita do verbo e recebe papel temático TEMA.

2) $\mathrm{O}$ argumento dos verbos existenciais/inacusativos também nasce na posição de argumento interno, ou seja, à direita do verbo (e nesta posição praticamente permanece) e recebe papel temático TEMA.

3) $\mathrm{O}$ argumento dos verbos impessoais/inacusativos nasce igualmente na posição de argumento interno, ou seja, à direita do verbo, (e nesta posição sempre permanece) e recebe papel temático TEMA.

O objetivo central desta etapa de análise norteou todo o trabalho: testar a possibilidade de seleção da variável tipo de verbo e medir a hipótese de que os verbos inacusativos, como uma classe natural agora mais ampliada, desfavorecem a concordância verbal por selecionarem argumentos internos, com o papel temático TEMA, e por terem argumentos mais livremente à direita. A diferença, neste momento, é que estamos buscando trabalhar com uma classe mais ampla de verbos inacusativos, constituída pelos inacusativos básicos, pelos existenciais e impessoais/inacusativos, pelas razões listadas em (1), (2) e (3) acima. Os resultados estão na TABELA 5 . 
Tabela 5: Efeito do tipo de verbo na concordância verbo/sujeito de terceira pessoa - dados de duas amostras: 16 falantes do Rio de Janeiro e uma só falante da região Nordeste

\begin{tabular}{l|l|l|l|l}
\hline Tipo de verbo & $\begin{array}{l}\text { 6 FALANTES } \\
\text { Freqüência } \\
\text { de concordância }\end{array}$ & $\begin{array}{l}\text { Peso } \\
\text { relativo } \\
\text { Nível } 7\end{array}$ & $\begin{array}{l}\text { 1 FALANTE } \\
\text { Freqüência } \\
\text { de concordância }\end{array}$ & $\begin{array}{l}\text { Peso } \\
\text { relativo } \\
\text { Nível 6 }\end{array}$ \\
\hline $\begin{array}{l}\text { Inacusativos } \\
\text { ampliados }\end{array}$ & $114 / 182=63 \%$ & $(0,43)$ & $45 / 102=44 \%$ & $(0,53)$ \\
\hline $\begin{array}{l}\text { Demais } \\
\text { verbos }\end{array}$ & $905 / 1080=84 \%$ & $(0,51)$ & $197 / 361=54 \%$ & $(0,49)$ \\
\hline Significância & $1019 / 1262=81 \%$ & 1.000 & & 0,698 \\
\hline Total & & $242 / 463=52 \%$ & \\
\hline
\end{tabular}

Embora os percentuais se apresentem na linha esperada, os resultados finais obtidos são os mesmos das análises anteriores: não há seleção da variável verbo. $\mathrm{Na}$ análise dos dados dos 16 falantes do Rio de Janeiro, a variável posição é que tira de cena o tipo de verbo de forma mais contundente; na análise dos dados da falante do Maranhão, residente em Brasília, é a variável traço semântico do sujeito que executa este papel de forma drástica. Em termos estatísticos, isto significa que, levando-se em consideração todo o conjunto de verbos, o efeito associado à categoria tipo de verbo é apenas aparente. Em outras palavras, o pressuposto efeito do tipo de verbo é resultado da ação de outros fatores, que participam da própria caracterização dos verbos inacusativos: posição do SN sujeito (ou do candidato a sujeito) na construção e animacidade.

A seguir, apresentamos na TABELA 6 os resultados de todas as variáveis lingüísticas selecionadas nas duas amostras, com foco especial para as que concorrem com o tipo de verbo. ${ }^{6}$ São elas: traço semântico do sujeito; posição e tipo de sintagma candidato a controle da concordância; e saliência fônica (na sua forma binária), um dos efeitos mais contundentes para o entendimento da variação da concordância verbal. A saliência fônica men-

\footnotetext{
6 Embora as variáveis paralelismo discursivo e paralelismo oracional não sejam relevantes para a discussão das idéias deste texto, decidimos colocá-las na TABELA 6 para que o leitor tenha uma visão de conjunto das variáveis lingüísticas selecionadas e da regularidade do comportamento dos efeitos de seus fatores. Para mais detalhes a respeito destas duas variáveis, ver Scherre \& Naro 1991; Scherre \& Naro, 1993; Scherre 1998; Cardoso, 2005.
} 
sura um traço morfofonológico do próprio verbo, que, até onde sabemos, não tem lugar na sintaxe abstrata de um modelo de orientação gerativista. Aliás, trata-se de uma propriedade tipicamente funcional, de base cognitiva mais ampla, já que leva em conta a oposição mais ou menos saliente (ou mais ou menos marcada) entre duas formas do paradigma, e não apenas a forma que ocorre na estrutura sob consideração; e leva também em conta a percepção desta oposição pelo falante.

Os resultados da TABELA 6, mesmo os colhidos de uma só falante, corroboram as conclusões de pesquisas anteriores, resumidas no início deste texto e aqui retomadas. Nesta etapa de análise, consideramos os argumentos dos verbos existenciais e impessoais, à direita, como um fator válido no grupo posição para buscar capturar a sua provável semelhança de efeito à do tradicional fator sujeito à direita do verbo.

Os resultados apresentados na TABELA 6 nos permitem concluir que:

1) Verbo com oposição mais saliente favorece concordância; verbo com oposição menos saliente desfavorece concordância (0,64 vs. 0,37 para a amostra do Rio de Janeiro; 0,80 vs. 0,21 para a falante do Maranhão).

2) Sujeito mais humano favorece concordância; sujeito menos humano desfavorece concordância $(0,56$ vs. 0,25 para a mostra do Rio de Janeiro; 0,55 vs. 0,21 para a falante do Maranhão).

3) Sujeito à esquerda e próximo do verbo favorece concordância; sujeito ou sintagma à direita do verbo desfavorece concordância: 0,65 vs. 0,20 e 0,19 para amostra do Rio de Janeiro; 0,65 vs. 0,37 e 0,21 para a falante do Maranhão. Os demais fatores da variável posição também apresentam resultados semelhantes: sujeito à esquerda mais distante ou com que relativo desfavorece concordância, se comparado internamente ao efeito do sujeito à esquerda e próximo ao verbo $(0,50$ vs. 0,65 para a amostra do Rio de Janeiro; 0,22 vs. 0,65 para a falante do Maranhão). Nas duas amostras, sujeito zero próximo desfavorece concordância e sujeito zero distante a favorece $(0,32$ vs. 0,59 e 0,39 vs. 0,55). 
Tabela 6: Efeito de cinco variáveis na concordância verbo/sujeito de terceira pessoa - dados de duas amostras: 16 falantes do Rio de Janeiro e uma só falante da região Nordeste

\begin{tabular}{|c|c|c|c|c|}
\hline Variáveis & $\begin{array}{l}16 \text { FALANTES } \\
\text { Freqüência } \\
\text { de concordância }\end{array}$ & $\begin{array}{l}\text { Peso } \\
\text { relativo } \\
\text { Nível } 6\end{array}$ & $\begin{array}{l}1 \text { FALANTE } \\
\text { Freqüência } \\
\text { de concordância }\end{array}$ & $\begin{array}{l}\text { Peso } \\
\text { relativo } \\
\text { Nível } 5\end{array}$ \\
\hline $\begin{array}{l}\text { 1) Saliência fônica } \\
\text { da oposição verbal } \\
\text { (+saliente) } \\
\text { (-saliente) }\end{array}$ & $\begin{array}{l}507 / 593=85 \% \\
512 / 669=77 \%\end{array}$ & $\begin{array}{l}0,64 \\
0,37\end{array}$ & $\begin{array}{l}159 / 219=73 \% \\
83 / 245=34 \%\end{array}$ & $\begin{array}{l}0,80 \\
0,21\end{array}$ \\
\hline $\begin{array}{l}\text { 2) Traço semântico do } \\
\text { sintagma candidato } \\
\text { a controle da concordância } \\
\text { (+humano) } \\
\text { (-humano) }\end{array}$ & $\begin{array}{l}878 / 1028=85 \% \\
141 / 234=60 \%\end{array}$ & $\begin{array}{l}0,56 \\
0,25\end{array}$ & $\begin{aligned} 227 / 399 & =57 \% \\
15 / \quad 64 & =23 \%\end{aligned}$ & $\begin{array}{l}0,55 \\
0,21\end{array}$ \\
\hline $\begin{array}{l}\text { 3) Posição, distância e tipo } \\
\text { do sintagma candidato } \\
\text { a controle da concordância } \\
\text { À esq. com até } 5 \\
\text { sílabas intervenientes }\end{array}$ & $572 / 639=90 \%$ & 0,65 & $129 / 214=60 \%$ & 0,65 \\
\hline $\begin{array}{l}\text { À esq. mais de } \\
5 \text { sil. intervenientes } \\
\text { ou com que relativo }\end{array}$ & $123 / 153=80 \%$ & 0,50 & $10 / 38=27 \%$ & 0,22 \\
\hline $\begin{array}{l}\text { À direita com } \\
\text { verbos existenciais } \\
\text { e impessoais }\end{array}$ & $45 / \quad 84=54 \%$ & 0,20 & $12 / 44=28 \%$ & 0,37 \\
\hline $\begin{array}{l}\text { À direita com } \\
\text { demais verbos }\end{array}$ & $20 / \quad 32=63 \%$ & 0,19 & $5 / 23=22 \%$ & 0,21 \\
\hline $\begin{array}{l}\text { Nulo próximo } \\
\text { Nulo distante }\end{array}$ & $\begin{array}{c}217 / 303=72 \% \\
42 / 49=86 \%\end{array}$ & $\begin{array}{l}0,32 \\
0,59\end{array}$ & $\begin{array}{l}47 / 94=50 \% \\
38 / 50=76 \%\end{array}$ & $\begin{array}{l}0,39 \\
0,55\end{array}$ \\
\hline $\begin{array}{l}\text { 4) Paralelismo discursivo } \\
\text { precedido de verbo } \\
\text { marcado } \\
\text { precedido de verbo } \\
\text { não marcado } \\
\text { isolado } / 1^{\circ} \text { da série }\end{array}$ & $\begin{array}{l}406 / 456=89 \% \\
33 / 83=40 \% \\
580 / 723=80 \%\end{array}$ & $\begin{array}{l}0,62 \\
0,22 \\
0,46\end{array}$ & $\begin{array}{l}129 / 178=72 \% \\
43 / 110=39 \% \\
70 / 176=40 \%\end{array}$ & $\begin{array}{l}0,67 \\
0,41 \\
0,37\end{array}$ \\
\hline $\begin{array}{l}\text { 5) Paralelismo oracional } \\
\text { sujeito com marca } \\
\text { sujeito com zero final }\end{array}$ & $\begin{aligned} 626 / 693 & =90 \% \\
69 / 101 & =68 \%\end{aligned}$ & $\begin{array}{l}0,52 \\
0,34\end{array}$ & $\begin{array}{l}116 / 182=64 \% \\
26 / 87=30 \%\end{array}$ & $\begin{array}{l}0,64 \\
0,24\end{array}$ \\
\hline Significância & & 0,007 & & 0,000 \\
\hline
\end{tabular}

A respeito da variável posição à direita, é importante enfatizar que não é apenas o sujeito tradicional que desencadeia a possibilidade de marca no verbo, desfavorecendo-a relativamente. Sintagmas à direita do verbo, interpretados ou não como sujeito, podem possibilitar a presença de marca de plural no verbo, especialmente nos casos de ser + predicativo: eram mais bomens/são doze horas. Na análise dos dados dos 64 falantes do Corpus Censo, Scherre \& Naro (1997: 103) verificaram que as construções com sujeito à 
direita do verbo apresentam $26 \%$ de verbos com marca explícita de plural (50/194), sendo a média global de concordância da ordem de 73\% (3369/ 4632). Os dados de ser + predicativo, não analisados em 1997, apresentam $47 \%$ de verbos com marca explícita de plural (157/331), ou seja, em termos de freqüências brutas, evidenciam mais concordância plural do que os próprios tradicionais sujeitos pospostos (chegaram duas colegas aqui/ganhô essas duas mininas). E, embora a concordância seja bem mais baixa nas construções com sujeito ou sintagma à direita do verbo, ainda não existe categoricidade de não-concordância neste ambiente, como ponderam Mioto et al. (2004: 162), ao se referirem à construção "chegou as carta". A maior saliência do verbo e o traço humano do sujeito ou do sintagma entram em jogo para favorecer a presença da marca de plural, mesmo num ambiente sintático que desfavorece a concordância plural e que favorece a interpretação do sintagma relevante como argumento interno, ou complemento verbal nos termos tradicionais. Os exemplos em 21 são evidências destas considerações:

(21) Verbos plurais com sintagmas nominais à sua direita
a. Passaram dois anos
b. Olha, até aqui chegaram os duzentos pneus
c. Apareceram trinta velhinhos
d. Vieram os dois pra casá aqui
e. Que num vão cem velhos
f. Só valem as garotas
g. Tinham dois na mesma carteira
h. E dançaram as duas
i. Já esgotaram os ingressos
j. Já acabaru minha prova todinha

Todavia, é fato que construções tradicionalmente classificadas ora como pessoais, com verbo dar, ora como impessoais, com o verbo fazer, indicando tempo, distância e também medida ou quantidade, apresentam, sim, uma taxa de verbos na forma singular quase categórica. Nos dados que estamos analisando, só encontramos um caso deste tipo com verbo no plural: fazem três anos. Estes fatos apontam para uma análise mais minuciosa dos dados em bases outras que não a inacusatividade como uma característica do verbo, se quisermos capturar alguma influência a mais do que as que já conseguimos capturar. 


\section{Conclusão}

Não há dúvida de que, em nossos dados, os verbos transitivos exibem predominantemente o argumento externo à sua esquerda; os verbos existenciais privilegiam um argumento único à sua direita; e os verbos impessoais só ocorrem com sintagmas à direita. Também não há dúvida de que, entre os casos de construções com sujeitos/sintagmas pospostos, há predominância de verbos intransitivos inacusativos, embora haja também muitas construções em que os inacusativos aparecem com argumento à esquerda do verbo. Entretanto, independentemente do tipo de verbo, qualquer argumento ou sintagma à direita do verbo tende, relativamente, a diminuir as marcas de concordância explicita.

Em verdade, mesmo para a ordem, a classe dos inacusativos não se revela homogênea, como demonstram Coelho (2000a: 142; 120; Coelho 2000b) e Duarte \& Silva (2005), e ponderam Ciríaco \& Cançado (2004: 218-223). Ciríaco \& Cançado (2004) enfatizam ainda que há problemas na subdivisão dos intransitivos em inacusativos e não-inacusativos. As evidências mais gerais da inacusatividade (i. possuir um só argumento com papel temático associado geralmente à posição de objeto e ii. a ordem VS ser aceita mais naturalmente já que o argumento do inacusativo é um objeto em sua origem que pode se mover para a posição de sujeito) não abrangem uniformemente a mesma classe de verbos (tanto para a análise de uma língua em particular como para uma análise de línguas diferentes). Além disso, segundo as autoras, as noções semânticas de agente, paciente, tema, etc, são demasiadamente vagas e intuitivas, embora constituam uma tentativa mais geral de definir papéis temáticos. Mesmo assim, analisando os dados da língua em uso, deparamo-nos com a necessidade de detalharmos as características de cada uma das subclasses de verbos intransitivos (incluindo as flutuações de transitividade dos verbos) e de verificarmos as nuances semânticas dos argumentos ou sintagmas desencadeadores de concordância, em especial, dos que se posicionam à direita do verbo.

No conjunto global dos dados, a única característica do verbo que influencia a concordância plural é a saliência fônica da oposição singular/ plural. Como característica intrínseca ao verbo, até onde caminhamos na análise, nada mais é relevante. O tipo de verbo, em especial, não revela efeito sobre a concordância, seja de acordo com a categorização tradicional, seja de acordo com a nova proposta de orientação gerativa. Em sínte- 
se, no que diz respeito à concordância, a classe dos inacusativos, nos termos até agora apresentados, é inoperante. Trabalhamos com o pressuposto de que a inacusatividade é uma propriedade do verbo, mas ainda precisamos medir se a inacusatividade como propriedade da estrutura traria novos resultados para o fenômeno da concordância verbal.

Portanto, pesquisas futuras podem e devem se voltar para uma codificação mais detalhada desses aspectos. Será oportuno observar a hierarquia dos papéis temáticos, mais especificamente, os papéis de AGENTE (Eles ABRI$R A M$ minha geladeira; eles FAZEM tema para filme), FONTE (é difícil conciliar a educação que as crianças RECEBEM em casa, eles VIAJAVAM muito), EXPERENCIADOR (Eles GOSTAM do assédio dos fãs. Eles VIVEM das pessoas, né?), TEMA (E nisso me CHEGA três rapazes), aqui exemplificados com argumentos com traço mais humano (cf. Brito \& Duarte 2003: 179-203 e Cançado 2003 para detalhes sobre o papel temático). Será igualmente oportuno efetuar uma análise mais detalhada de todas as construções que ocorrem com sujeito ou sintagma à direita do verbo, para capturar nuances semânticas outras envolvidas nas expressões que indicam tempo, distância, quantidade, valor, e para verificar o que estas construções têm a nos revelar para o entendimento mais global da concordância verbal, da ordem e, eventualmente, do próprio fenômeno da inacusatividade. Desta forma, talvez possa ser possível dar conta do encaixamento sintático da variação da concordância de número e também da neutralização da concordância de gênero de algumas estruturas.

E-mails: scherre@unb.br anaro@gmx.net carolrcsecret@gmail.com

\section{REFERÊnCIAS Bibliográficas}

Anjos Almeida, S. E. 1999. Um estudo variacionista da concordância verbosujeito na fala pessoense. João Pessoa: Dissertação de Mestrado, UFPB. Bechara, E. 1999. Moderna gramática portuguesa. Rio de Janeiro: Lucerna. Berlink, R. A. 1989. A construção V SN no português do Brasil: Uma visão diacrônica do fenômeno da ordem. In: F. TARallo (org.) Fotografias Sociolingüísticas. São Paulo: Pontes. 95-112. 
Bortoni-Ricardo, S. M. 1985. The urbanization of rural dialect speakers - $A$ sociolinguistic study in Brazil. New York: Cambridge University Press.

BuRzIO, L. 1986. Italian syntax: A government-binding approach. Dordrecht: Reisel Publishing Company.

Cardoso, C. R. 2005. Variação da concordância verbal no indivíduo: Um confronto entre o lingüístico e o estilístico. Brasília: Dissertação de Mestrado, UnB. Cançado, M. 2003. Um estatuto teórico para os papéis temáticos. In: A. L. Müller, E. V. Negrao \& M. J. Foltran (orgs.) Semântica formal. São Paulo: Contexto. 95-124.

Ciríaco, L. \& M. CANÇADO. 2004. Inacusatividade e inergatividade no PB. Cadernos de estudos lingüísticos, Campinas, IEL 46.2: 207-225.

Coelho, I. L. 2000a. A ordem V DP em construções monoargumentais: Uma restrição sintático-semântica. Florianópolis: Tese de Doutorado, UFSC. . 2000b. Sobre a natureza do verbo monoargumental na ordem V NP. ORGANON - Estudos da lingua falada, Porto Alegre, UFRGS 14.28\&29: 75-93.

Cunha, C. \& L. F. L. Cintra. 1985. Nova gramática do português contemporâneo. Rio de Janeiro: Nova Fronteira.

Brito, A. M. \& I. Duarte. 2003. Aspectos semânticos da gramática do português. In: M. H. M. MAteus et al. Gramática da língua portuguesa. 5 ed. Revista e ampliada Lisboa: Caminho. 127-272.

Dillinger, M. 1991. Forma e função na lingüística. D.E.L.T.A. 7.1: 395407.

Duarte, I. 2003. Subclasses de verbos e esquemas relacionais. In: M. H. M. Mateus et al. Gramática da língua portuguesa. 5 ed. Revista e ampliada Lisboa: Caminho. 295-316.

Duarte, M. E. \& H. S. Silva. 2005. From VS to SV order with unaccusative verbs in Brazilian Portuguese. Comunicação apresentada no NWAV34. Nova Iorque: Universidade de Nova Iorque.

Du BoIs, J. W. 1987. The discourse basis of ergativity. Language, LSA, Baltimore, 63.4: 805-855.

Eliseu, A. M. G. S. 1984. Verbos ergativos do português: Descrição e análise. Ms., Universidade de Lisboa.

Fernandes, F. 1998. Dicionário de verbos e regimes. São Paulo: Globo.

GuY, G. R. 1998. Varbrul: Análise avançada. Cadernos de Tradução. 2.ed. 1, Porto Alegre, UFRGS. 25-46 [Tradução de A. M. Stahl Zilles] 
. 1981. Linguistic variation in Brazilian Portuguese: Aspects of the phonology, syntax and language history. Philadelphia: PhD Dissertation, University of Pennsylvania.

GuY, G. R. \& A. ZiLles. 2007. Sociolingüística quantitativa - instrumental de análise. São Paulo: Parábola.

Graciosa, D. M. D. 1991. Concordância verbal na fala culta carioca. Rio de Janeiro: Dissertação de Mestrado, UFRJ.

Kato, M. A. 2000. A restrição de monoargumentalidade da ordem VS no português do Brasil. Fórum Lingüístico 2.1: 92-127.

Labov, W. 1975. Sociolinguistic patterns. Philadelphia: University of Pennsylvania Press.

Lyons, J. 1979. Introdução à lingüística teórica. São Paulo: Nacional.

Mioto, C., M. C. Figueredo Silva \& R. E. V. Lopes. 2004. Novo manual de sintaxe. Florianópolis: Insular.

Monguilhott, I. O. S. 2001. Variação na concordância verbal de terceira pessoa do plural na fala dos floripolitanos. Forianópolis: Dissertação de Mestrado, UFSC.

\& I. L. Coelho. 2002. Um estudo da concordância verbal de terceira pessoa em Florianópolis. In: V. PAULINo (org.) Variação e mudança no português falado da região sul. Pelotas: Educat. 189-216.

Naro, A. J. The social and structural dimensions of a syntactic change. Language, LSA, Baltimore 57.1: 63-98.

\& M. Lemle. 1976. Syntactic diffusion. In: S. B. Steever et alii (orgs.) Papers from the parasession on diachronic syntax. Chicago: Chicago Linguistic Society. 221-241.

\& M. M. P. SCHERRE. 1999a. A influência de variáveis escalares na concordância verbal. A cor das letras 3: 17-34. Revista do Departamento de Letras e Artes da Universidade Estadual de Feira de Santana. Feira de Santana.

. 1999b. Sobre o efeito da saliência na concordância verbal na fala moderna, na escrita antiga e na escrita moderna. In: D. MourA (org.) Os múltiplos usos da língua. Maceió: EDUFAL. 26-37.

Naro, A. J. \& S. J. Votre. 1992. Mecanismos funcionais do uso da língua: Função e forma. D.E.L.T.A. 8.2: 285-290.

. 1999. Discourse motivations for linguistic regularities: verb/ subject order in spoken Brazilian Portuguese. Probus 11: 73-98.

Nascimento, M. 1990. Teoria gramatical e "mecanismos funcionais do uso da língua". D.E.L.T.A. 6.1: 83-98. 
Franchi, C., E. V. Negrão \& E. ViotTi. 1998. Sobre as orações impessoais com ter/haver. D.E.L.T.A. 14/Especial: 105-131.

Nicolau, E. M. D. 1984. A ausência de concordância verbal em português: Uma abordagem sociolingüística. Belo Horizonte:. Dissertação de Mestrado, UFMG.

Oliveira e Silva, G. M. \& M. M. P. Scherre (orgs.) 1996. Padrões sociolingüústicos - Análise de fenômenos variáveis do português falado no Rio de Janeiro. Rio de Janeiro: Tempo Brasileiro.

Paiva, M. C. \& M. E. Duarte. 2003 (orgs.) Mudança lingüística em tempo real. Rio de Janeiro: Contra Capa e FAPERJ.

Perini, M. A. 1995. Gramática descritiva do português. São Paulo: Ática. 2006. Princípios de lingüística descritiva. São Paulo: Parábola.

Pilati, E. 2006. Aspectos sintáticos e semânticos das oraçôes com ordem verbosujeito no português do Brasil. Brasília: Tese Doutorado, UnB.

Pintzuk, S. 1998. VARBRUL programs. Ms., University of Pennsylvania.

Robinson, J., H. Lawrence \& S. Tagliamonte. 2001. GoldVarb 2001. A multivariate analysis application for Windows. Ms., University of York.

Rodtigues, A. C. S. 1987. A concordância verbal no português popular em São Paulo. São Paulo: Tese de Doutorado, USP.

Sankoff, D. 1988. Variable rules. In: U. Ammon, N. Dirttmar \& K. J. MATTHeIr (orgs.) Sociolinguistics - An international handbook of the science of language and society. Berlin/New York: Walter de Gruyter. 984-998.

Scherre, M. M. P. 1998. Paralelismo lingüístico. Estudos da Linguagem, Belo Horizonte 7/2: 9-28.

\& A. J. Naro. 1997. A concordância de número no português do Brasil: Um caso típico de variação inerente. In: D. HorA (org.) Diversidade lingüística no Brasil. João Pessoa: Idéia. 93-115.

. 1991. Marking in discourse: "Birds of a feather". Language Variation and Change 3.1: 23-32.

. 1993. Duas dimensões do paralelismo formal na concordância de número no português popular do Brasil. D.E.L.T.A. 3.1: 1-14.

- 1998. Restrições sintáticas e semânticas no controle da concordância verbal em português. Fórum lingüístico, Florianópolis 1.1: 45-71.

. 2003. Análise quantitativa e tópicos de interpretação do Varbrul. In: M. C. Mollica \& M. L. Braga (orgs.) Introdução à sociolingüústica: O tratamento da variação. São Paulo: Contexto. 147-178. 
. 2006. Mudança sem mudança: A concordância de número no português brasileiro. SCRIPTA, Belo Horizonte 9.18: 109-131. \& C. R. Cardoso. 2005. Evaluating the role of verb type in subject/ verb agreement in Brazilian Portuguese. Comunicação apresentada no NWAV34. New York: New York University.

Scherre, M. M. P., C. R. Cardoso \& A. J. Naro. 2007. Inacusatividade, ordem e concordância verbal. Caderno de Resumos do CONGRESSO INTERNACIONAL DA ABRALIN 5: 777-778. Belo HorizonteMG: Faculdade de Letras da UFMG.

Tagliamonte, S. A. 2006. Analyzing sociolinguistic variation. Cambridge: Cambridge University Press.

Vogt BARDen, L. T. 2004. A variação na concordância verbal na terceira pessoa do plural. Porto Alegre: Dissertação de Mestrado, Pontifícia Universidade Católica do Rio Grande do Sul.

Votre, S. J. \& A. J. Naro. 1989. Mecanismos funcionais do uso da língua. D.E.L.T.A. 5.2: 169-184.

Weinreich, U., W. Labov \& M. I. Herzog. 1968. Empirical foundations for a theory of language change. In: W. P. Lehmann \& Y. MaLKiel. Directions for historical linguistics: A symposium. Austin-London: University of Texas Press. 95-199. 